\title{
Synthesis and Characterization of Aromatic Polyamides Derived from New Phenylated Aromatic Diamines
}

\author{
Yoshimitsu SaKaguchi* and Frank W. HaRris \\ Department of Polymer Science, The University of Akron, \\ Akron, OH44325, U.S.A.
}

(Received May 8, 1992)

\begin{abstract}
Four new phenylated aromatic diamines, 1,4-bis(4-amino-3,5-diphenylphenyl)benzene (1a), 1,3-bis(4-amino-3,5-diphenylphenyl)benzene (1b), 1,4-bis(4-aminophenyl)-2,3,5triphenylbenzene (2a), and 1,4-bis(4-aminophenyl)-2,3,5,6-tetraphenylbenzene (2b) were synthesized and polymerized with terephthaloyl chloride (TPC) and isophthaloyl chloride (IPC). All the polyamides showed high thermal stability with $5 \%$ weight-loss temperatures in the range of 466$524^{\circ} \mathrm{C}$ in air or nitrogen, and no melting peak below their decomposition temperatures. The polymers containing $m$-catenation had glass transition temperatures in the range of $275-349^{\circ} \mathrm{C}$, and were soluble in $N$-methyl-2-pyrrolidone (NMP). The rigid rod-like polyamides consisting all para-oriented linkages showed no clear glass transition. In the rod-like polymers, polymer 2a/TPC showed good solubility in NMP, and preliminary optical microscope observation for the $20 \%$ solution showed an anisotropic property.
\end{abstract}

KEY WORDS Aromatic Polyamide / Phenyl Substituent / Phenylated Aromatic Diamine / Thermal Stability / Solubility / Rigid-Rod / Optical Anisotropy /

Aromatic polyamides, such as poly(paraphenylene terephthalamide), show excellent mechanical properties and good thermal properties. However, these polymers are infusible and show limited solubility in organic solvents. There are general concepts for structural modification to improve the solubility of polymers as follows: introduction of flexible or kinked structure, decrease of structural regularity and symmetry, and incorporation of side chains or bulky substituents. To increase the solubility while maintaining the thermal stability, the structural modification with whole aromatic system is particularly prefered. $^{1-10}$ From this view point, the introduction of phenyl side groups into the polymer chain is considered as an effective approach. In the case of aromatic rigid rod-like polyamides, several polymers having aromatic substituents were reported to be soluble in organic solvents, ${ }^{11-14}$ and display anisotropic properties. ${ }^{1-13}$ An advantage to obtain a soluble rigid rod-like polyamide lies in its possible application to the reinforcing material in molecular composite as well as the high-strength and high-modulus fiber.

The authors reported the preparation of two new series of phenylated aromatic diamines and polymerization of polyimides derived from these diamines. ${ }^{15}$ This report shows the synthesis of new aromatic polyamides by the polymerization of these phenylated diamines and diacid chlorides, and some characterizations of the polymers obtained. The details of the preparation of these diamines are also described.

* Present address: Toyobo Research Center, Toyobo Co., Ltd., 1-1 Katata 2-chome, Ohtsu, 520-02, Japan. 


\section{EXPERIMENTAL}

\section{Materials}

$\mathrm{N}$-Methyl-2-pyrrolidone (NMP) was distilled over $\mathrm{P}_{2} \mathrm{O}_{5}$ under reduced pressure. Terephthaloyl chloride (TPC) and isophthaloyl chloride (IPC) were distilled under reduced pressure. Other chemicals were used without further purification.

\section{Monomer Synthesis}

1,4-Bis(1,3-dibenzoyl-2-propyl)benzene (3a). Terephthaldicarboxaldehyde $\quad(28.4 \mathrm{~g}, \quad 0.212$ $\mathrm{mol})$ and acetophenone $(152.1 \mathrm{~g}, 1.27 \mathrm{~mol})$ were dissolved in $700 \mathrm{ml}$ of $95 \%$ ethanol. Potassium hydroxide $(29.6 \mathrm{~g}, 0.528 \mathrm{~mol})$ in $32 \mathrm{ml}$ of water was added to the solution dropwise. A precipitate appeared soon. The reaction mixture was stirred and refluxed for 3 hours, then filtered. The solid obtained was washed with $500 \mathrm{ml}$ of fresh $95 \%$ ethanol under reflux; Yield $11 \mathrm{~g}(93 \%)$. mp $184-192^{\circ} \mathrm{C}$ (lit. ${ }^{16}$ $\left.204-205^{\circ} \mathrm{C}\right) .{ }^{1} \mathrm{H} \mathrm{NMR}\left(\mathrm{CDCl}_{3}\right) \delta=3.6(\mathrm{~d}, 8 \mathrm{H}$, $\left.\mathrm{CH}_{2}\right), 4.2(\mathrm{~m}, 2 \mathrm{H}, \mathrm{CH}), 7.4-7.8(\mathrm{~m}, 16 \mathrm{H}$, aromatic $\mathrm{H}), 8.2 \mathrm{ppm}(\mathrm{m}, 8 \mathrm{H}$, aromatic $\mathrm{H})$.

1,4-Phenylenebis- $\gamma, \gamma^{\prime}-\left(2^{\prime}, 6^{\prime}\right.$-diphenylpyrylium)tetrafluoroborate (4a). Triphenylmethanol $(113.4 \mathrm{~g}, 0.436 \mathrm{~mol})$ was dissolved in $700 \mathrm{ml}$ of acetic anhydride at $65^{\circ} \mathrm{C}$, then the solution was cooled to room temperature with a water bath. $49 \%$ Fluoboric acid $(78.0 \mathrm{~g}, 0.435 \mathrm{~mol})$ was added dropwise maintaining the reaction at room temperature. Then, $\mathbf{3 a}(90.0 \mathrm{~g}, 0.156 \mathrm{~mol})$ was added, and the resulting suspension was stirred for 17 hours. The product was collected, washed with THF several times, and then dried; Yield $106 \mathrm{~g} \mathrm{(96 \% ).}$

1,4-Bis(4-nitro-3,5-diphenylphenyl)benzene (5a). Nitromethane $(236 \mathrm{~g}, 3.86 \mathrm{~mol})$ was added to a solution of potassium $(15.5 \mathrm{~g}, 0.396 \mathrm{~mol})$ in $580 \mathrm{ml}$ of tert-butanol. This solution was added to a stirred suspension of $4 \mathbf{a}(100 \mathrm{~g}$, $0.140 \mathrm{~mol}$ ) in $580 \mathrm{ml}$ of tert-butanol. Another solution of potassium $(15.5 \mathrm{~g}, 0.396 \mathrm{~mol})$ in $580 \mathrm{ml}$ of tert-butanol was added, then the mixture was stirred under reflux for 2 hours.
The precipitate was collected, stirred in hot water, filtered, and dried; Yield $64.5 \mathrm{~g} \mathrm{(74 \% ).}$ After the recrystallization from dioxane-ethanol $(4: 1)$, the needles obtained showed the melting point at $341-344^{\circ} \mathrm{C}$; IR (KBr) 1360 and $1530 \mathrm{~cm}^{-1} \quad\left(\mathrm{NO}_{2}\right)$. Anal. Calcd for $\mathrm{C}_{42} \mathrm{H}_{28} \mathrm{~N}_{2} \mathrm{O}_{4}: \mathrm{C}, 80.75 \% ; \mathrm{H}, 4.52 \% ; \mathrm{N}$, $4.48 \%$. Found: C, $80.37 \%$; H, $4.73 \%$; N, $4.36 \%$.

1,4-Bis(4-amino-3,5-diphenylphenyl)benzene (1a). A suspension of $5 \mathbf{a}(12.0 \mathrm{~g}, 0.0192 \mathrm{~mol})$ in $600 \mathrm{ml}$ of 2-methoxyethanol was stirred and heated to $100^{\circ} \mathrm{C}$. Stannous chloride $(48.7 \mathrm{~g}$, $0.216 \mathrm{~mol}$ ) which was dissolved in $115 \mathrm{ml}$ of hydrochloric acid was added to the suspension. After stirred around $100^{\circ} \mathrm{C}$ for 5 hours, the same amount of stannous chloride solution was added, and the reaction was continued for another 15 hours. The reaction mixture was poured into $1000 \mathrm{ml}$ of water and filtered. The solid obtained was neutralized by ammonium hydroxide, washed with water, and dried; Yield $10.6 \mathrm{~g}(97 \%)$. The crude product was recrystallized from xylene several times; $\mathrm{mp}$ $310-312^{\circ} \mathrm{C}$. IR (KBr) 3360 and $3450 \mathrm{~cm}^{-1}$ (NH). Anal. Calcd for $\mathrm{C}_{42} \mathrm{H}_{32} \mathrm{~N}_{2}$ : C, $89.33 \%$; $\mathrm{H}, 5.71 \%$; N, $4.96 \%$. Found: C, $89.52 \%$; H, $5.76 \% ; \mathrm{N}, 4.71 \%$.

1,3-Bis(1,3-dibenzoyl-2-propyl)benzene (3b). The reaction between isophthaloyldicarboxaldehyde and acetophenone was carried out following a similar procedure with the preparation of 3a. During the reaction, two phases separated. The lower layer, which was viscous and dark brown, was separated and stirred with ethanol. After the ethanol was removed by decantation, the viscous residue was dried; Yield $77 \%$. ${ }^{1} \mathrm{H}$ NMR $\left(\mathrm{CDCl}_{3}\right)$ $\delta=3.3\left(\mathrm{~d}, 8 \mathrm{H}, \mathrm{CH}_{2}\right), 4.0(\mathrm{~m}, 2 \mathrm{H}, \mathrm{CH})$, $6.4-7.9 \mathrm{ppm}(\mathrm{m}, 24 \mathrm{H}$, aromatic $\mathrm{H})$.

1,3-Phenylenebis- $\gamma, \gamma^{\prime}-(2,6$-diphenylpyryli-

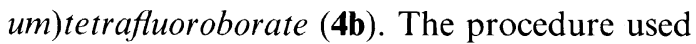
in the preparation of $\mathbf{4 a}$ was applied to that of 4b; Yield 35\%.

1,3-Bis(4-nitro-3,5-diphenylphenyl)benzene (5b). A similar procedure with the preparation 
of $\mathbf{5 a}$ was applied to that of $\mathbf{5 b}$. After the reaction, water was added to the reaction mixture. The precipitate was collected and dried; Yield $92 \%$. mp $250-258^{\circ} \mathrm{C}$. IR (KBr) 1360 and $1530 \mathrm{~cm}^{-1}\left(\mathrm{NO}_{2}\right)$.

1,3-Bis(4-amino-3,5-diphenylphenyl)benzene (1b). The procedure used in the preparation of 1a was applied to that of $\mathbf{1 b}$; Yield $97 \%$. The crude product was recrystallized from toluene/ethanol. mp $212-213^{\circ} \mathrm{C}$. IR ( $\left.\mathrm{KBr}\right) 3380$ and $3480 \mathrm{~cm}^{-1}\left(\mathrm{NH}_{2}\right)$. Anal. Calcd for $\mathrm{C}_{42} \mathrm{H}_{32} \mathrm{~N}_{2}$ : C, $89.33 \% ; \mathrm{H}, 5.71 \% ; \mathrm{N}, 4.96 \%$. Found: C, $89.78 \%$; H, 5.70\%; N, $4.71 \%$.

1,3-Bis(4-nitrophenyl)acetone (7). 4-Nitrophenylacetic acid (6) $(100 \mathrm{~g}, 0.552 \mathrm{~mol})$ was dissolved in $600 \mathrm{ml}$ of acetic anhydride. Keeping the system at $80^{\circ} \mathrm{C}, 300 \mathrm{ml}(2.16 \mathrm{~mol})$ of triethylamine was added dropwise and the solution was stirred for 2 hours. The solution was poured into $1000 \mathrm{ml}$ of $10 \%$ hydrochloric acid and filtered. The solid obtained was ground into a powder, and stirred in $500 \mathrm{ml}$ of refluxing concentrated hydrochloric acid for 8 hours. The product was collected and washed with water several times; Yield $79.8 \mathrm{~g}(96 \%)$. IR $(\mathrm{KBr}) 1340$ and $1520 \mathrm{~cm}^{-1} \quad\left(\mathrm{NO}_{2}\right)$, $1720 \mathrm{~cm}^{-1}(\mathrm{C}=\mathrm{O}) .{ }^{1} \mathrm{H}$ NMR $\left(\mathrm{CDCl}_{3}\right) \delta=8.0$, $7.3(\mathrm{dd}, J=8 \mathrm{~Hz}$, aromatic $\mathrm{H}), 4.0 \mathrm{ppm}(\mathrm{s}, 4 \mathrm{H}$, $\mathrm{CH}_{2}$ ).

2,5-Bis(4-nitrophenyl)-3,4-diphenylcyclopentadienone (8). Benzil $(54.6 \mathrm{~g}, 0.260 \mathrm{~mol})$ and $7(78.0 \mathrm{~g}, 0.260 \mathrm{~mol})$ were added to $390 \mathrm{ml}$ of ethanol. After the stirred solution was heated nearly to the boiling point, a solution of $7.8 \mathrm{~g}$ $(0.139 \mathrm{~mol})$ of potassium hydroxide in $40 \mathrm{ml}$ of ethanol was added slowly. The reaction mixture was stirred for 1 hour, and then allowed to cool to room temperature. The product was collected and washed with ethanol several times; Yield $44 \mathrm{~g}(36 \%)$. IR (KBr) 1340 and $1510 \mathrm{~cm}^{-1}\left(\mathrm{NO}_{2}\right), 1715 \mathrm{~cm}^{-1}(\mathrm{C}=\mathrm{O})$.

1,4-Bis(4-nitrophenyl)-2,3,5-triphenylbenzene (9a). Phenylacetylene $(19.3 \mathrm{~g}, 0.189 \mathrm{~mol})$, $8(30.0 \mathrm{~g}, 0.063 \mathrm{~mol})$ and $130 \mathrm{ml}$ of $o$-dichlorobenzene was stirred at $180^{\circ} \mathrm{C}$ for two hours. The reaction mixture was allowed to cool to room temperature, and poured into $500 \mathrm{ml}$ of hexane. The product was collected by filtration and dried; Yield $22.9 \mathrm{~g}(66 \%)$.

1,4-Bis(4-aminophenyl)-2,3,5-triphenylbenzene (2a). A solution of $9 \mathrm{a}(20.0 \mathrm{~g}, 0.0365 \mathrm{~mol})$ in $250 \mathrm{ml}$ of 2-methoxyethanol was stirred and heated to $80^{\circ} \mathrm{C}$. A solution of stannous chloride $(82.2 \mathrm{~g}, 0.364 \mathrm{~mol})$ in $130 \mathrm{ml}$ of hydrochloric acid was added. Thereafter, the mixture was stirred around $100^{\circ} \mathrm{C}$ for 5 hours. The reaction mixture was allowed to cool to room temperature, and poured into $600 \mathrm{ml}$ of water and filtered. The solid obtained was neutralized by ammonium hydroxide, washed with water, and dried; Yield $10.0 \mathrm{~g}(61 \%)$. The crude product was recrystallized from toluene; $\mathrm{mp}$ $256-258^{\circ} \mathrm{C}$. IR (KBr) 3460 and $3480 \mathrm{~cm}^{-1}$ $\left(\mathrm{NH}_{2}\right) .{ }^{1} \mathrm{H} \mathrm{NMR}\left(\mathrm{CDCl}_{3}\right) \delta=3.3(\mathrm{~s}, 4 \mathrm{H}$, $\left.\mathrm{NH}_{2}\right), 6.0-7.3 \mathrm{ppm}(\mathrm{m}, 24 \mathrm{H}$, aromatic $\mathrm{H})$. Anal. Calcd for $\mathrm{C}_{36} \mathrm{H}_{28} \mathrm{~N}_{2}: \mathrm{C}, 88.49 \% ; \mathrm{H}$, $5.78 \% ; \mathrm{N}, 5.73 \%$. Found: C, $88.85 \% ; \mathrm{H}$, $5.83 \% ; \mathrm{N}, 5.58 \%$.

1,4-Bis(4-nitrophenyl)-2,3,5,6-tetraphenylbenzene $(9 \mathbf{b})$. The procedure used in the preparation of $\mathbf{9 a}$ was applied to that of $\mathbf{9 b}$, except the reaction time was extended to 17 hours; Yield $63 \%$.

1,4-Bis(4-aminophenyl)-2,3,5,6-tetraphenylbenzene $(\mathbf{2 b})$. The procedure used in the preparation of $\mathbf{2 a}$ was applied to that of $\mathbf{2} \mathbf{b}$; Yield $45 \%$. The crude product was recrystallized from pyridine; $\mathrm{mp} 453^{\circ} \mathrm{C}$ (DSC). IR (KBr) 3380 and $3450 \mathrm{~cm}^{-1}\left(\mathrm{NH}_{2}\right)$. Anal. Calcd for $\mathrm{C}_{42} \mathrm{H}_{32} \mathrm{~N}_{2}$ : C, $89.33 \%$; H, 5.71\%; $\mathrm{N}, 4.96 \%$. Found: C, $88.54 \% ; \mathrm{H}, 5.64 \%$; N, $4.92 \%$.

\section{Polymerization}

As an example, the polymerization of $\mathbf{2 a}$ and terephthaloyl chloride (TPC) is shown below.

In a $25 \mathrm{ml}$ of three-necked flask equipped with a mechanical stirrer, a nitrogen inlet and a drying tube were placed 2a $(0.4000 \mathrm{~g}$, $0.8187 \mathrm{~mol}$ ) and $2.9 \mathrm{~g}$ of NMP. After the system was cooled below $5^{\circ} \mathrm{C}$ with an ice bath, TPC $(0.1662 \mathrm{~g}, 0.8186 \mathrm{~mol})$ was added and stirred 
for $30 \mathrm{~min}$. Thereafter, the reaction was continued at room temperature for 15 hours. The polymer solution was poured into $500 \mathrm{ml}$ of methanol. The polymer precipitated was collected and dried.

The other polymers were synthesized similarly. The polymerization concentrations were selected between $5 \%$ and $20 \%$. When lithium carbonate or lithium chloride was added in the polymerization system, an equivalent with the amide linkages was added after the addition of the monomers.

\section{Measurements}

Inherent viscosities were measured at a concentration of $0.5 \mathrm{~g} \mathrm{dl}^{-1}$ at $30^{\circ} \mathrm{C}$. Infrared (IR) spectra were recorded on a Beckman FT2100 spectrometer with $\mathrm{KBr}$ disks. ${ }^{1} \mathrm{H}$ NMR spectra were recorded on a Varian T60 NMR spectrometer. Thermogravimetric analysis (TGA) was conducted with a DuPont Model 951 thermogravimetric analyzer at a heating rate of $10^{\circ} \mathrm{Cmin}^{-1}$ in $100 \mathrm{ml} \mathrm{min}^{-1}$ of $\mathrm{N}_{2}$ or air flow. Differential scanning calo- rimetry (DSC) was performed on a DuPont 1090 thermal analyzer in combination with a DSC cell at a heating rate of $20^{\circ} \mathrm{C} \mathrm{min}^{-1}$ in $60 \mathrm{mlmin}^{-1}$ of $\mathrm{N}_{2}$ flow. Wide angle X-ray scattēring (WAXS) was conducted on a Rigaku X-ray diffractometer with nickelfiltered $\mathrm{Cu}-K_{\alpha}$ radiation $(38 \mathrm{kV}, 30 \mathrm{~mA})$ and a Laue camera. Solubility of the polymers was evaluated by mixing the polymers and solvents for 24 hours. Optical microscopic observation was carried out on a Nikon type 104 polarized-light transmission microscope.

\section{RESULTS AND DISCUSSION}

\section{Monomer Synthesis}

New diamines containing two phenyl groups on the $o$-positions of amino groups were prepared as shown in Scheme 1. Terephthaldicarboxaldehyde and isophthaldicarboxaldehyde were reacted with acetophenone to yield the tetraketones $\left(\mathbf{3 a},{ }^{16} \mathbf{3 b}\right)$. The bispyrylium salts $(\mathbf{4 a}, \mathbf{4 b})$ were derived from $\mathbf{3 a}$ and $\mathbf{3 b}$, though relatively long reaction time ( 17 hours)

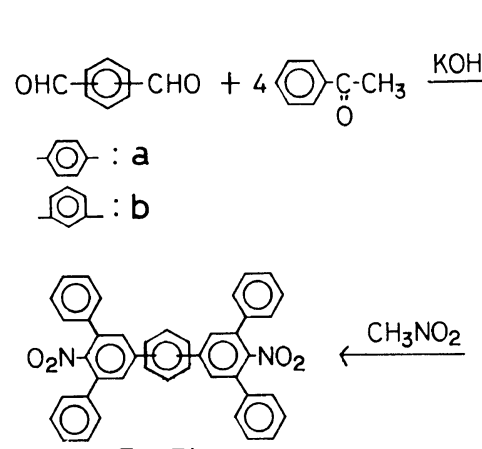

$\underline{5 a}, \underline{5 b}$<smiles>O=C(Cc1ccccc1)Cc1cc(CCc2ccccc2)cc(CCc2ccccc2)c1</smiles><smiles>[13CH3]</smiles>

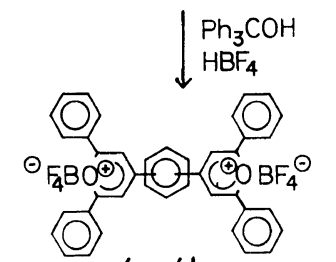

$\underline{4 a}, \underline{4 b}$<smiles>C[SbH2]C(Cl)Cl</smiles><smiles>Nc1c(-c2ccccc2)cc(-c2ccc(-c3cc(-c4ccccc4)c(N)c(-c4cccc(-c5cc(-c6ccccc6)cc(-c6ccccc6)c5)c4)c3)cc2)cc1-c1ccccc1</smiles>

Scheme 1. 


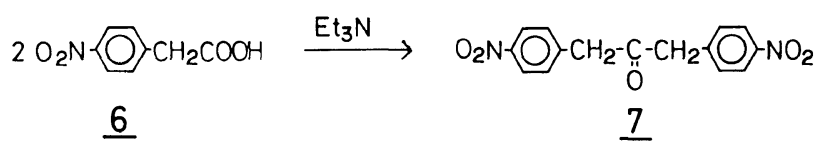

$\underline{6}$

$\underline{7}$

$\downarrow \begin{gathered}\mathrm{Ph}-\mathrm{C}-\mathrm{C}-\mathrm{Ph} \\ \mathrm{O} 0 \mathrm{O}\end{gathered}$
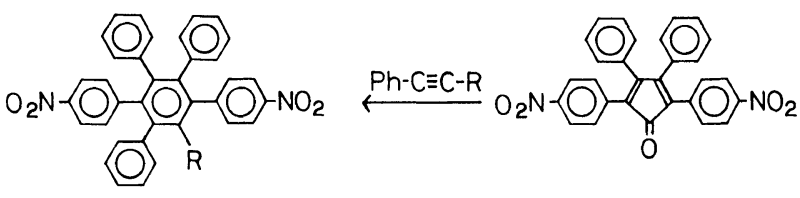

$\mathrm{R}=\mathrm{H}: \underline{9 \mathrm{a}}$

$\underline{8}$

$R=\langle 0\rangle: \underline{9 b}$
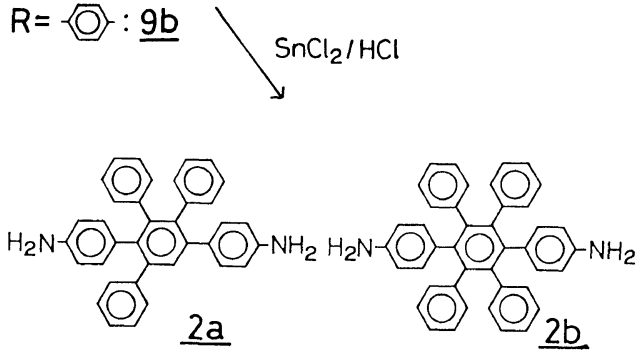

Scheme 2.

was necessary due to the heterogeneous reaction. The dinitro compounds $(\mathbf{5 a}, \mathbf{5 b})$ were prepared by using a method for the condensation of 2,4,6-triphenylpyrylium tetrafluoroborate and nitromethane in the presence of potassium tert-butoxide. ${ }^{17}$ The diamines (1a, 1b) were obtained by the reduction of $\mathbf{5 a}$ and $\mathbf{5 b}$ with stannous chloride as a reducing agent. In the case of $1 \mathbf{a}$, the yield was sometimes low because the solubility of 5a was poor.

The other new diamines containing phenyl groups on the middle phenylene of $p$ terphenylene were prepared as shown in Scheme 2. Condensation of 4-nitrophenylacetic acid was carried out following a literature. ${ }^{18}$ below, and the decarboxylation under reflux of

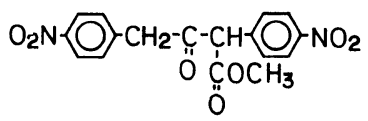

$\mathrm{HCl}$ gave 1,3-bis(4-nitrophenyl)acetone (7). The product obtained had a structure as shown

The cyclopentadienone (8) was synthesized by using a similar method with the preparation of tetraphenylpentadienone. ${ }^{19}$ The dinitro compounds $(9 \mathrm{a}, 9 \mathbf{9})$ were prepared by the Diels-Alder reaction. ${ }^{20}$ Because of steric hindrance, the reaction of $\mathbf{8}$ and diphenylacetylene needed a longer reaction time (17 hours) than that of $\mathbf{8}$ and phenylacetylene. The diamines $(\mathbf{2} \mathbf{a}, \mathbf{2} \mathbf{b})$ were obtained by the reduction of $9 \mathrm{a}$ and $9 \mathrm{~b}$ with stannous chloride as a reducing agent. Recrystallization of $\mathbf{2} \mathbf{b}$ was carried out from pyridine due to poor solubility in xylene or toluene, which was used for the recrystallization of the other three diamines. Pure $\mathbf{2 b}$ showed a sharp endothermic peak at $453^{\circ} \mathrm{C}$ on DSC measurement. It seems that the highly symmetrical structure of $\mathbf{2} \mathbf{b}$ made the thermal stability of crystal extremely high in comparison with the other diamines prepared.

\section{Polymerization}

Polymerization of the diamines and terePolym. J., Vol. 24, No. 10, 1992 

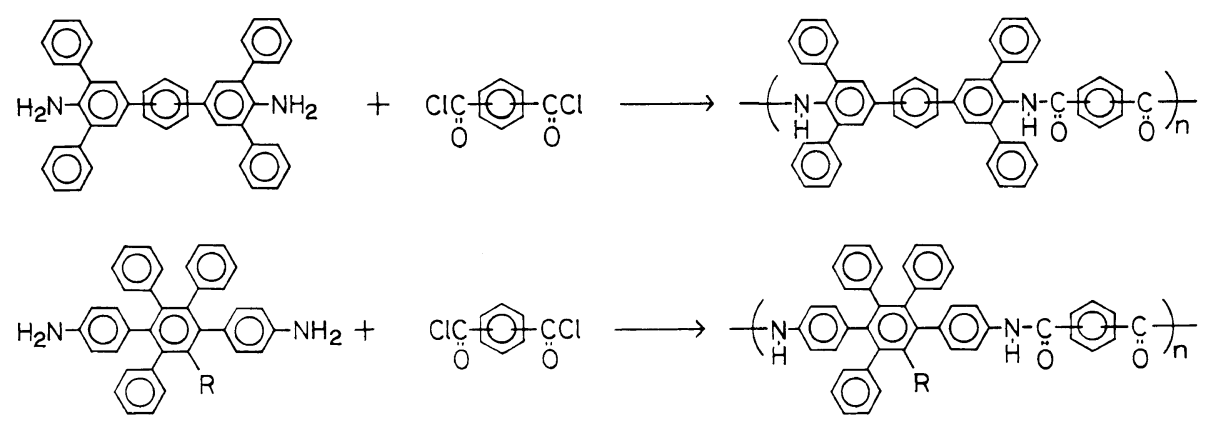

Scheme 3.

Table I. Synthesis of polyamides

\begin{tabular}{|c|c|c|c|c|c|c|c|}
\hline \multirow{2}{*}{ Diamine } & \multirow{2}{*}{$\begin{array}{l}\text { Diacid } \\
\text { chloride }\end{array}$} & \multicolumn{2}{|c|}{ Condition } & \multirow{2}{*}{ Outlook } & \multirow{2}{*}{$\frac{\text { Yield }}{\%}$} & \multirow{2}{*}{$\frac{\eta_{\mathrm{inh}}^{\mathrm{a}}}{\mathrm{dl} \mathrm{g}^{-1}}$} & \multirow{2}{*}{ Film } \\
\hline & & Concn. & Additive & & & & \\
\hline \multirow[t]{3}{*}{$1 \mathbf{a}$} & TPC & $5 \%$ & no & Turbid & 89 & 0.83 & no \\
\hline & TPC & $7 \%$ & $\mathrm{Li}_{2} \mathrm{CO}_{3}$ & Transparent & 85 & 0.97 & no \\
\hline & IPC & $7 \%$ & no & Transparent & 93 & 0.47 & yes \\
\hline \multirow[t]{2}{*}{$1 b$} & TPC & $8 \%$ & no & Transparent & 99 & 0.62 & yes \\
\hline & IPC & $13 \%$ & no & Transparent & 89 & 0.28 & no \\
\hline \multirow[t]{2}{*}{$2 a$} & TPC & $14 \%$ & no & Transparent & 97 & 2.87 & yes \\
\hline & IPC & $14 \%$ & no & Transparent & 97 & 0.88 & yes \\
\hline \multirow[t]{4}{*}{$\mathbf{2 b}$} & TPC & $8 \%$ & no & Precipitate & 78 & $0.46^{\mathrm{b}}$ & no \\
\hline & TPC & $14 \%$ & $\mathrm{LiCl}$ & Cloudy & 83 & $0.93^{\mathrm{b}}$ & no \\
\hline & IPC & $14 \%$ & no & Precipitate & 91 & $0.49^{b}$ & yes \\
\hline & IPC & $15 \%$ & $\mathrm{LiCl}$ & Cloudy & 81 & $0.46^{b}$ & yes \\
\hline
\end{tabular}

${ }^{\text {a }}$ Inherent viscosity measured at a concentration of $0.5 \mathrm{~g} \mathrm{dl}^{-1}$ in NMP at $30^{\circ} \mathrm{C}$ except for $\mathbf{b}$.

b NMP containing $\mathrm{LiCl}$ was used as a solvent.

chloride (IPC) was carried out by low-temperature solution condensation in NMP (Scheme 3). The results are summarized in Table I.

Precipitate of 1a/TPC polyamide appeared during the polymerization in NMP. When polymerized in the presence of $\mathrm{Li}_{2} \mathrm{CO}_{3}$, the reaction mixture was a clear solution and gave the polymer with inherent viscosity of 0.97 . However, the molecular weight was not high enough to form a film. Polymers, 1a/IPC, $1 \mathbf{b} /$ TPC, and 1b/IPC was polymerized as a homogeneous solution. The polymers 1a/IPC and 1b/TPC gave flexible and tough films. Relatively low viscosities of these polymers may be attributed to the steric hindrance of the diamines due to the bulky side groups on the $o$-position of the amino groups.

The polymerization using $\mathbf{2 a}$ gave polyamides having good solubility and high viscosity to form tough films. The polymer made of 2a and TPC gave the highest inherent viscosity of 2.87 in this series. In the case of $\mathbf{2 b}$, on the other hand, both polymers derived from TPC and IPC precipitated during the polymerization in NMP. The polymerization in the presence of $\mathrm{LiCl}$ did not improve the solubility remarkably, and did not increase the inherent viscosity so much 
Table II. Characterization of polyamides

\begin{tabular}{|c|c|c|c|c|c|c|c|}
\hline \multicolumn{2}{|c|}{ Polymer } & \multirow{2}{*}{$\frac{\eta_{\mathrm{inh}}}{\mathrm{dl} \mathrm{g}^{-1}}$} & \multirow{2}{*}{$\frac{T_{\mathrm{g}}^{\mathrm{a}}}{{ }^{\circ} \mathrm{C}}$} & \multicolumn{2}{|c|}{ TGA $/{ }^{\circ} \mathrm{C}^{\mathrm{b}}$} & \multicolumn{2}{|c|}{ Solubility $^{\mathrm{c}}$} \\
\hline Diamine & $\begin{array}{c}\text { Diacid } \\
\text { chloride }\end{array}$ & & & $\mathrm{N}_{2}$ & Air & NMP & $\mathrm{CHCl}_{3}$ \\
\hline \multirow[t]{2}{*}{$1 \mathrm{a}$} & TPC & 0.97 & - & 508 & 482 & + & - \\
\hline & IPC & 0.47 & 299 & 482 & 485 & ++ & - \\
\hline \multirow[t]{2}{*}{$1 \mathrm{~b}$} & TPC & 0.62 & 327 & 477 & 467 & ++ & - \\
\hline & IPC & 0.28 & 275 & 466 & 567 & ++ & - \\
\hline \multirow[t]{2}{*}{$2 a$} & TPC & 2.87 & - & 508 & 493 & ++ & - \\
\hline & IPC & 0.88 & 349 & 509 & 520 & ++ & - \\
\hline \multirow[t]{2}{*}{$2 \mathbf{b}$} & ТPC & 0.93 & - & 516 & 524 & - & - \\
\hline & IPC & 0.49 & - & 514 & 516 & - & - \\
\hline
\end{tabular}

a $T_{\mathrm{g}}$ determined by DSC at a heating rate of $20^{\circ} \mathrm{Cmin}^{-1}$ in $\mathrm{N}_{2}$.

b $5 \%$ weight-loss temperature on TGA at a heating rate of $10^{\circ} \mathrm{C} \mathrm{min}^{-1}$ in $100 \mathrm{ml} \mathrm{min}{ }^{-1}$ flow of $\mathrm{N}_{2}$ or air.

c ++ , soluble; + , partially soluble; - , insoluble.

\section{Characterization}

Thermal transition behaviors were evaluated by DSC measurement. The polymers containing $m$-catenation showed the glass transitions at $275-349^{\circ} \mathrm{C}$, except for $\mathbf{2 b} / \mathrm{IPC}$ polyamide (Table II). The polymers in which all linkages are $p$-catenated did not show clear glass transition. All the polymers did not show melting behavior below their decomposition temperatures, though X-ray diffraction measurement showed that the polymers had more or less semi-crystalline characteristics. The $\mathrm{X}$-ray diffraction photograph of $\mathbf{2 a} / \mathrm{TPC}$ is shown in Figure 1 as an example.

All the polymers showed good thermal stability on the TGA measurements; $5 \mathrm{wt} \%$ weight-loss temperatures were in the range of $466-524^{\circ} \mathrm{C}$. There was no remarkable difference in measuring atmosphere, $\mathrm{N}_{2}$ or air.

The polymers derived from $\mathbf{1 b}$ and $\mathbf{2 a}$ showed good solubility in NMP. The flexible structure by $m$-catenation in the former and the interference of polymer chain packing by the unsymmetrical structure in the latter contributed to improve their solubilities. The diamines which have $p$-catenated and symmetrical structure (1a and $\mathbf{2 b}$ ) made the polymers less soluble in NMP. Monomer crystallinity of

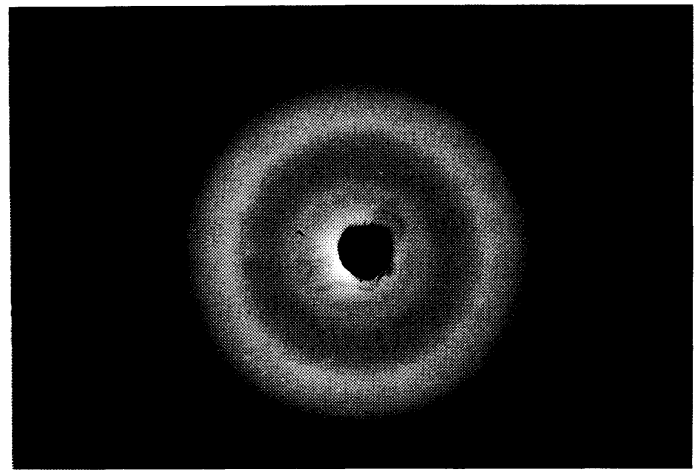

Figure 1. X-Ray diffraction photograph of the 2a/TPC polyamide.

2b, which showed an extremely high melting temperature, may be responsible for the fact that the polymers derived from $\mathbf{2 b}$ had the lowest solubility in this series.

In the three rigid-rod polyamides, 2a/TPC polyamide showed the highest viscosity and the best solubility. Preliminary microscopic observation for $\mathbf{2 a}$ /TPC polyamide solution in NMP was carried out at room temperature. A $20 \%$ solution was obtained from the polymerization solution directly, and observed through an optical microscope under cross polarization. Some part of the solution showed 
Table III. Microscopic observation of 2a/TPC polyamide solution in NMP containing $\mathrm{LiCl}$ under crossed polarization

\begin{tabular}{clc}
\hline $\begin{array}{c}\text { Polymer } \\
\text { concentration }\end{array}$ & \multicolumn{1}{c}{ Under shear } & No shear \\
\hline $20 \%$ & Colorful birefringence & $\begin{array}{c}\text { Partially colorful } \\
\text { birefringence } \\
\text { Monochlomic } \\
\text { birefringence }\end{array}$ \\
$17 \%$ & Colorful birefringence & Dark \\
$15 \%$ & Bright $\leftrightarrow$ dark & Dark \\
$10 \%$ & Slightly bright $\leftrightarrow$ dark & Dark \\
$5 \%$ & Dark & \\
\hline
\end{tabular}

colorful birefringence and the other part showed monochlomic birefringence. In the case of a $20 \%$ NMP solution containing $\mathrm{LiCl}$, some part showed colorful birefringence, and the other part showed color only under applied shear, and relaxed to an isotropic phase quickly. The relation of microscopic appearance and polymer concentration is listed in Table III. These anisotropic behaviors suggest that $2 \mathbf{a}$ /TPC polyamide solution in NMP forms a liquid crystalline phase. Further evaluations, including the concentration effect on the absolute viscosity of the polymer solution, are involved in the future work.

\section{REFERENCES}

1. M. Kakimoto, M. Yoneyama, and Y. Imai, J. Polym. Sci., Polym. Chem. Ed., 26, 149 (1988).

2. S. S. Mohite, N. N. Maldar, and C. S. Marvel, $J$. Polym. Sci., Polym. Chem. Ed., 26, 2777 (1988).

3. F. Akutsu, K. Matsuo, K. Naruchi, and M. Miura, Polym. Commun., 30, 182 (1989).

4. Y. Oishi, S. Harada, M. Kakimoto, and Y. Imai, $J$. Polym. Sci., Polym. Chem. Ed., 27, 3393 (1989).

5. A. E. Lozano, J. G. de la Campa, and J. de Abajo, Makromol. Chem., Rapid Commun., 11, 471 (1990).
6. Y. Oishi, H. Takado, M. Yoneyama, M. Kakimoto, and Y. Imai, J. Polym. Sci., Polym. Chem. Ed., 28, 1763 (1990).

7. J. Lin, Y. Yuki, H. Kunisada, and S. Kondo, J. Appl. Polym. Sci., 40, 2113 (1990).

8. M. Xie, Y. Oishi, M. Kakimoto, and Y. Imai, $J$. Polym. Sci., Polym. Chem. Ed., 29, 55 (1991).

9. H. Jeong, M. Kakimoto, and Y. Imai, J. Polym. Sci., Polym. Chem. Ed., 29, 767 (1991).

10. G. Liou, Y. Oishi, M. Kakimoto, and Y. Imai, $J$. Polym. Sci., Polym. Chem. Ed., 29, 995 (1991).

11. J. Y. Jadhav, W. R. Krigbaum, and J. Preston, Macromolecules, 21, 538 (1988).

12. J. Y. Jadhav and W. R. Krigbaum, J. Polym. Sci., Polym. Chem. Ed., 27, 1175 (1989).

13. W. Hatke, H. Schmidt, and W. Heitz, J. Polym. Sci., Polym. Chem. Ed., 29, 1387 (1991).

14. W. Hatke, H. Land, H. Schmidt, and W. Heitz, Makromol. Chem., Rapid Commun., 12, 235 (1991).

15. F. W. Harris and Y. Sakaguchi, Proc. Polym. Mater. Sci. Eng., 60, 187 (1989).

16. S. V. Krivun and G. N. Dorofeenko, Khim. Getero. Soedi., 2, 656 (1966).

17. W. Foerst, "Newer Method of Preparative Organic Chemistry," Vol. III, Academic Press, New York, 1964, p 415.

18. H. Saikachi and Y. Taniguchi, Yakugaku Zasshi, 88, 1054 (1968).

19. E. C. Horning, Ed., "Org. Synth.," Coll. Vol. 3, John Wiley \& Sons, New York, 1955, p 806.

20. L. F.Fieser, "Organic Experiments," 2nd ed, Heath, D. C., Co., Lexington, MA, 1968, p 297. 